\title{
Influence of clay and organic amendments on the yield and zinc nutrition of blackgram in coastal sandy soil
}

T. Dhivya and R. Singaravel

Received : 22.06.2018; Revised : 02.11.2018; Accepted : 10.11.2018

MEMBERS OF RESEARCH FORUM:

Corresponding author : T. Dhivya, Department of Soil Science and Agricultural Chemistry, Faculty of Agriculture, Annamalai University, Annamalai Nagar (T.N.) India
Co-authors :

R. Singaravel, Department of Soil Science and Agricultural Chemistry, Faculty of Agriculture, Annamalai University, Annamalai Nagar (T.N.) India

\begin{abstract}
Summary
Zinc is an important micronutrient required by plants and animals. $\mathrm{Zn}$ is one of the deficient nutrient in sandy soil of coastal agro ecosystem owing the unfavourable soil characteristics namely low organic matter, CEC and high leaching etc. A pot experiment was carried out in the Department of Soil Science and Agricultural Chemistry, Annamalai University during Feb.Apr.' 2017, to evaluate the influence of clay and organic amendments viz., FYM and humic acid on the yield and $\mathrm{Zn}$ nutrition of blackgram. The soil was sandy, slightly saline with $\mathrm{pH}$ 8.07 and represented low available NPK and Zn status. In a Completely Randomized Design, the following treatments namely $\mathrm{T}_{1}$ - Control (100\% recommended dose of NPK), $\mathrm{T}_{2}-\mathrm{NPK}+$ $\mathrm{ZnSO}_{4} @ 25 \mathrm{~kg} \mathrm{ha}^{-1}, \mathrm{~T}_{3}-\mathrm{T}_{2}$ + clay @ $20 \mathrm{tha}^{-1}, \mathrm{~T}_{4}-\mathrm{T}_{3}$ +humic acid @ $20 \mathrm{~kg} \mathrm{ha}^{-1}, \mathrm{~T}_{5}-\mathrm{T}_{3}+\mathrm{FYM}$ @ $12.5 \mathrm{t} \mathrm{ha}^{-1}$ were studied using four replications. Black gram variety ADT-3 was grown, during the crop period, various growth and yield parameters and yield were recorded. The results of the study indicated that the application of clay and organic amendments were efficient in improving the growth, yield and $\mathrm{Zn}$ nutrition of blackgram. Among the treatments $\mathrm{T}_{4}$, application of $\mathrm{NPK}+\mathrm{ZnSO}_{4} @ 25 \mathrm{~kg} \mathrm{ha}^{-1}+$ clay @ $20 \mathrm{t} \mathrm{ha}^{-1}+$ humic acid @ $20 \mathrm{~kg} \mathrm{ha}{ }^{-1}$ accounted for a significant increase in the yield and nutrition of blackgram by recording higher content and uptake of macro and micro nutrient $\mathrm{Zn}$.
\end{abstract}

Key words : Coastal sandy, Blackgram, Yield, Zinc nutrition

How to cite this article : Dhivya, T. and Singaravel, R. (2018). Influence of clay and organic amendments on the yield and zinc nutrition of blackgram in coastal sandy soil. Asian J. Soil Sci., 13 (2) : 95-98 : DOI : 10.15740/HAS/AJSS/13.2/95-98. 